JPDN ISSN 2579-6461 (Online) ISSN 2460-6324 (Print)

Jurnal Pendidikan Dasar Nusantara

Volume 6| Nomor 1 | Juli 2020 |

DOI: https://doi.org/10.29407/jpdn.v6i1.14711

\title{
Pengembangan Media Tata Surya Berbasis Macromedia Flash Sebagai Inovasi Pembelajaran DARING Untuk Siswa SD
}

\author{
Sutrisno Sahari ${ }^{1}$, Wahyudi \\ Sutrisno@unpkediri.ac.id, wahyudi@unpkdr.ac.id \\ PGSD, FKIP, Universitas Nusantara PGRI Kediri \\ No Handphone: 082234979233
}

\begin{abstract}
Abstrak: Berdasarkan permasalahan yang ada dimana dimasa pandemi covid-19 siswa dituntut belajar dari rumah dengan pembelajaran dalam jaringan (DARING). Dengan demikian peneliti bertujuan untuk mengembangkan media pembelajaran yang inovatif dan valid digunakan untuk siswa. Metode yang digunakan dalam penelitian ini yaitu menggunakan metode R\&D dengan model ADDIE (Analysis, Design, Development, Implementation dan Evaluation). Hasil penelitian menunjukan bahwa media tata surya layak digunakan untuk siswa sekolah dasar dibuktikan dengan hasil validitas ahli media dengan nilai kevalidan mencapai 90\% dengan kategori layak. Validitas kelayakan media berdasarkan kesesuian gambar, warna, font, tata letak tulisan, gambar, animasi, dan suara. Sedangkan ahli materi validitas mencapai $83 \%$ berdasarkan kopentensi inti (KI), indikator, kesesuaian dengan perkembangan kognitif anak. Sedangkan ahli bahasa sebesar $87 \%$ dengan kategori layak berdasarkan tikat perkembangan bahasa siswa. Dengan demikian produk media tata surya valid dan layak digunakan dalam pembelajaran di sekolah dasar.
\end{abstract}

Kata kunci: Media tata surya, macromedia flash, pembelajaran dalam jaringan.

\section{Macromedia Flash Based Solar System Media Development As A DARING Learning Innovation For Elementary School Students}

\begin{abstract}
Based on the existing problems, during the Covid-19 pandemic, students were required to learn from home by online learning (DARING). Thus, the researcher aims to develop innovative and valid learning media for students. The method used in this study is $\mathrm{R} \& \mathrm{D}$ method with the ADDIE model (Analysis, Design, Development, Implementation and Evaluation). The results showed that the solar system media was suitable for use by elementary school students as evidenced by the results of the validity of the media expert with a validity value of $90 \%$ with the feasible category. The validity of media eligibility is based on the suitability of images, colors, fonts, text layout, images, animation and sound. While the validity of material experts reached $83 \%$ based on core competence (KI), indicators, suitability with children's cognitive development. Meanwhile, $87 \%$ of linguists were categorized as feasible based on the level of language
\end{abstract}


Sutrisno. Pengembangan Media Tata Surya...

development of students. Thus, the solar system media products are valid and suitable for use in learning in elementary schools.

Keywords: Solar system media, macromedia flash, online learning.

\section{PENDAHULUAN}

Pendidikan merupakah suatu dasar dalam kehidupan manusia, tanpa adanya pendidikan di suatu negara maka negara tersebut akan sulit berkembang. Pendidikan dapat dilakukan secara tatap muka, maupun teknologi dalam jaringan. Teknologi dalam jaringan atau disebut dengan DARING dengan cara memanfaatkan media pembelajaran berupa video, mengunakan aplikasi zoom, maupun aplikasi multimedia interaktif yang mana bias dimanfaatkan dalam proses pembelajaran.

Tidak dipungkiri bahwa sebagian besar negara pada tahun 2020 mendapatkan bencana berupa virus corona (Covid-19) yang mana telah menghambat beberapa sektor pemerintahan baik ekonomi, pendidikan, dan sektor yang lainya. Salah satu negara yang derdampak covid-19 adalah Indonesia dimana sektor pendidikan mengalami dampak yang luar biasa. Pemerintah membuat kebijakan pembelajaran dilakukan secara DARING untuk mengendalikan dan menghindari penularan covid-19 dilingkungan pendidikan. Setiap pendidik dituntut untuk mampu melakukan pembelajaran secara DARING dan membuat inovasi pembelajaran yang mampu di pahami siswa secara baik meski tidak tatap muka secara langsung. Menurut Milman (2015) penggunaan teknologi digital dapat memungkinkan mahasiswa dan dosen melaksanakan proses pembelajaran walaupun mereka ditempat yang berbeda. Selain itu menurut Wicaksono (2016) menyatakan bahwa peran media sangat penting dalam proses pembelajaran agar materi yang disampaikan oleh guru cepat sampai dan mudah diterima secara maksimal oleh siswa. Dengan demikian salah satu inovasi pembelajaran yang dapat digunakan tanpa harus tatap muka secara langsung yaitu dengan cara memanfaatkan media TIK untuk menunjang pembelajaran secara DARING. Media TIK bias berupa video pembelajaran, macromedia flash, e-book dan media yang lainnya.

Macromedia flash merupakan media pembelajran yang bias digunakan secara online maupun ofline. Dengan demikian media tersebut bias di pejari berulang-ulang tanpa mengunakan kuota internet. Media macromedia flash dilengkapi dengan beberapa video, gambar, tek tulisan yang tidak monoto sehingga media ini dapat menjadi solusi 
Sutrisno. Pengembangan Media Tata Surya...

dalam permasalahan pembelajran secara DARING. Menurut (Nopriyanti, 2015) menyatakan bahwa produk multimedia pembelajaran interaktif efektif meningkatkan hasil belajar siswa. Sedangkan menurut (Mukmin, 2020) multimedia interaktif macromedia flash merupakan media pembelajaran yang inovativ, serta berdampak positif terhadap pembelajaran tematik yang ada di sekolah dasar. Menurut Sumarsih (2016) tidak adanya media pembelajaran dapat menghambat proses pembelajaran.

Berdasarkan permasalahan yang ada di atas tujuan penelitian ini adalah untuk mengembangkan media pembelajaran tata surya berbasis macromedia flash sebagai inovasi pembelajaran DARING untuk siswa sekolah dasar yang valid dan layak digunakan. Dengan adaya media pembelajaran ini diharapkan mampu menjadi solusi dalam permasalahan pembelajaran DARING yang ada di sekolah dasar.

\section{METODE}

Memuat garis besar metode penelitian, prosedur pelaksanaan, populasi dan sampel, alat, bahan, atau instrumen, dan teknik analisis. Jika diperlukan, ada informasi mengenai kisi-kisi instrumen.

Metode penelitian yang dikembangkan dalam penelitian ini yaitu R\&D (Research and Development). Pada penelitian ini akan dihasilkan suatu produk media pembelajaran makromedia flash. Metode penelitian ini merujuk pada model ADDIE (Analysis, Design, Development, Implementation dan Evaluation) yang dikembangkan oleh Robert Maribe Branch (2009). Dalam penelitian pengembangan ini yang dihasilkan berupa produk media pembelajaran yang Valid dan inovatif bagi siswa SD. Penelitian pengembangan ini dibatasi pada tahap developme yaitu peneliti hanya pada tahap validitas ahli media, bahasa, dan materi. Berikut langkah penelitian R\&D yang telah dikembangkan peneliti

Tabel 1. Langkah-langkah penelitian R \& D (Research and Development)

\begin{tabular}{|c|c|c|}
\hline No & Langkah Utama & Rincian Langkah \\
\hline $\mathbf{1}$ & Analysis & $\begin{array}{c}\text { Pada tahap ini peneliti melakukan analisis media } \\
\text { pembelajaran apa yang cocok digukan dalam kondisi } \\
\text { pandemik covid-19 yang sesuai dengan tingkat } \\
\text { perkembangan siswa SD. }\end{array}$ \\
\hline $\mathbf{2}$ & Evalusi & $\begin{array}{c}\text { Peneliti melakukan evaluasi apakah media yang akan } \\
\text { dikembangkan sudah sesuai dan memberikan inovasi } \\
\text { pembelajaran yang valid. }\end{array}$ \\
\hline
\end{tabular}


Sutrisno. Pengembangan Media Tata Surya...

\begin{tabular}{|c|c|c|}
\hline \hline No & Langkah Utama & \multicolumn{1}{c|}{ Rincian Langkah } \\
\hline 3 & Design & $\begin{array}{l}\text { Membuat rancangan produk berupa media pembelajaran } \\
\text { tata surya berbasis macromedia flash meliputi } \\
\text { a) Mempersiapkan Spesifikasi produk dan mendesain } \\
\text { tema, materi, bentuk penulisan, interaksi dan umpan } \\
\text { balik, warna, video, audio, animasi, latar belakang, } \\
\text { menu, tombol-tombol. }\end{array}$ \\
\hline $\mathbf{4}$ & Developme & $\begin{array}{l}\text { Pada tahap ini peneliti melakukan pengembangan } \\
\text { media tata surya berbasis macromedia flash yang } \\
\text { disesuaikan dengan tahapan design sehingga menjadi } \\
\text { produk. }\end{array}$ \\
\hline $\mathbf{5}$ & \multicolumn{2}{|c|}{$\begin{array}{l}\text { Evaluasi digukan untuk mengetahui kevalidan produk } \\
\text { yang digunkan apabila produk layak maka bisa } \\
\text { digunakan dalam pembelajaran. }\end{array}$} \\
\hline
\end{tabular}

Sedangkan untuk teknik analisis data yang digunakan pada penelitian ini adalah analisis data deskriptif kuantitatif dan analisis data deskriptif kualitatif. Deskriptif kuantitatif dan deskriptif kualitatif tersebut digunakan untuk mengolah data validitas produk tata surya.

\section{HASIL}

\section{A. Spesifikasi Produk yang Dikembangkan}

Produk yang dihasilkan dapat digunakan sebagai penunjang dalam pembelajaran bagi siswa kelas VI SD. Produk ini dapat digunakan secara klasikan di dalam kelas maupun digunakan sebagai media belajar mandiri oleh siswa. Sehingga penggunaan produk tidak terbatas untuk digunakan di dalam kelas saja.

\section{Komponen Multimedia}

Dalam multimedia ini, terdapat beberapa komponen yang digunakan, yaitu:

a. Background dan Warna

Pemilihan background dan warna dalam multimedia ini disesuaikan dengan tema pembelajaran. Dalam multimedia ini dipelajari tema terkait dengan tata surya, sehingga pemilihan background didominasi dengan tema planet-planet dan juga benda langit lainnya. Sedangkan warna tombol dan lain sebagainya menyesuaikan dengan warna background, sehingga cenderung bersifat penuh warna.

b. Jenis Huruf 
Sutrisno. Pengembangan Media Tata Surya...

Dalam multimedia ini, digunakan beberapa jenis huruf yang berfungsi sebagai pembeda kalimat yang bersifat penjelasan atau kalimat yang bersifat instruksi. Jenis font yang digunakan diantaranya:

1) Balonku yang digunakan sebagai judul macromedia.

2) Big Bang! yang digunakan untuk menjelaskan materi.

Kedua jenis huruf tersebut dipilih dengan mempertimbangkan kemenarikan dan juga kesesuaian dengan kognitif siswa kelas 6 SD.

c. Audio

Dalam multimedia ini, terdapat audio berupa suara yang muncul saat pengguna mengarahkan kursor pada tombol yang mungkin akan dipilih. Suara audio berfungsi untuk memberikan kesan menarik sehingga tidak monoton. Penggunaan audio dalam multimedia ini juga bersifat instrumental dan bukan pada tampilan materi.

\section{Tombol yang Digunakan Beserta Fungsinya}

Pada produk multimedia interaktif berbasis K-13 ini terdapat beberapa tombol yang digunakan untu mendukung berjalannya multimedia ini. Berikut beberapa tombol yang digunakan dalam multimedia ini dapat dilihat pada tabel 1 dibawah ini.

Tabel 1. Tombol-Tombol yang Terdapat Pada Multimedia Interaktif

\begin{tabular}{|l|l|}
\hline Tombol-tombol & \multicolumn{1}{|c|}{ Fungsi dan kegunaan } \\
\hline
\end{tabular}


Sutrisno. Pengembangan Media Tata Surya...

\begin{tabular}{|l|l|}
\hline & $\begin{array}{l}\text { Tombol "Quiz" berisikan soal latihan yang digunakan untuk } \\
\text { mengukur kemampuan siswa setelah menggunakan } \\
\text { multimedia interaktif dalam proses pembelajaran }\end{array}$ \\
$\begin{array}{l}\text { Tombol "Profil Pembuat" berisikan profil pembuat } \\
\text { multimedia interaktif. }\end{array}$ & $\begin{array}{l}\text { Tombol "Next" berfungsi untuk melanjutkan kegiatan } \\
\text { selanjutnya. }\end{array}$ \\
\hline & $\begin{array}{l}\text { Tombol "Back" berfungsi untuk kembali ke halaman } \\
\text { sebelumnya. }\end{array}$ \\
\hline & \begin{tabular}{l} 
Tombol "Menu" berfungsi untuk kembali ke halaman menu. \\
\hline
\end{tabular}
\end{tabular}

\section{Tampilan Produk Multimedia}

a. Tampilan Awal Produk

Pada tampilan awal terdapat judul multimedia yaitu media pembelajaran "Tata Surya". Bagian bawah sebelah kiri terdapat tombol "exit", Bagian bawah sebelah kanan terdapat tombol "start". Berikut gambar tampilan pembuka dapat dilihat pada gambar 1 dan 2 .
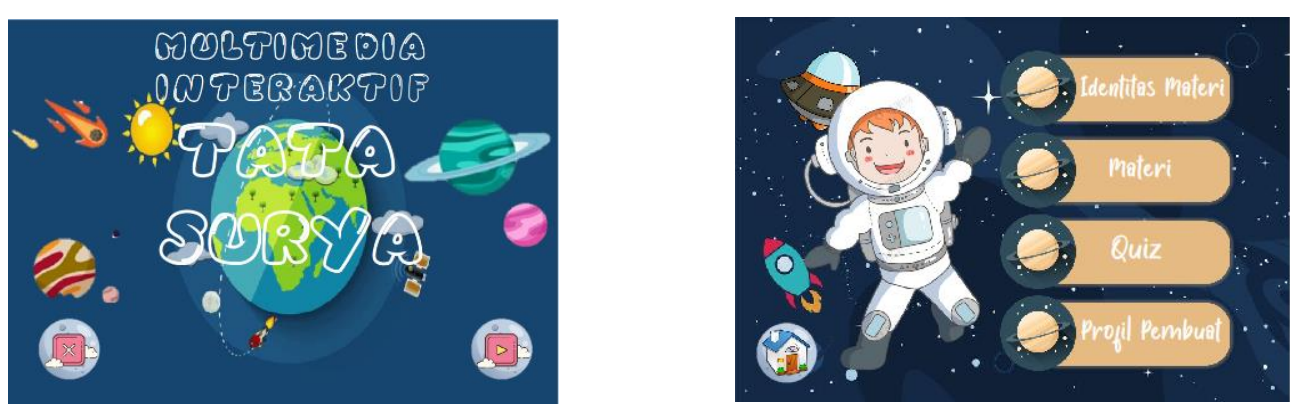
Sutrisno. Pengembangan Media Tata Surya...

Gambar 1. Tampilan awal

Gambar 2. Tampilan Menu Utama

b. Menu Informasi Materi : berisikan informasi materi maple, kelas, semester, tema, subtema,dan juga materi. Pada tampilan ke dua terdapat KD dan Indikator dari multimedia interaktif.

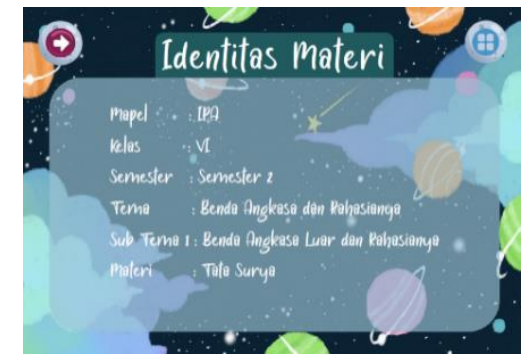

Gambar.3 Tampilan Menu Identitas Materi

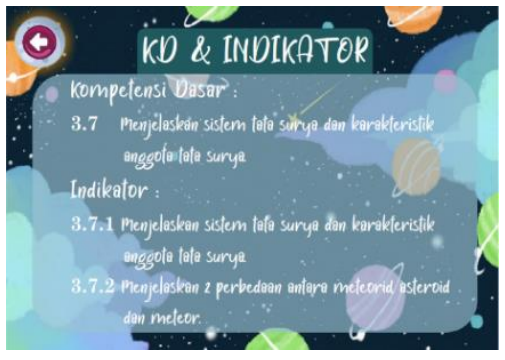

Gambar.4 Tampilan KD \& Indikator

c. Menu Materi : berfungsi untuk menampilan materi Tata Surya yang akan disampaikan pada multimedia interaktif. Pada tampilan menu ini terdapat tombol next dan back pada kiri atas, dan juga tombol menu yang berfungsi untuk kembali pada tampilan menu. Tampilan tersebut seperti pada gambar 5.

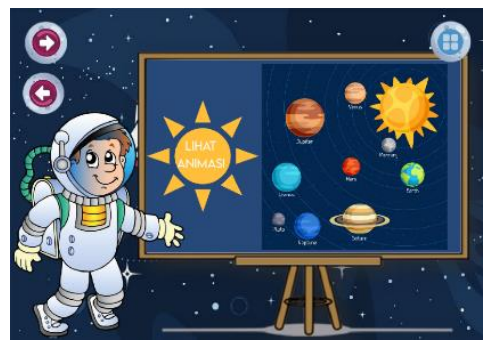

Gambar 5 Tampilan Menu Materi

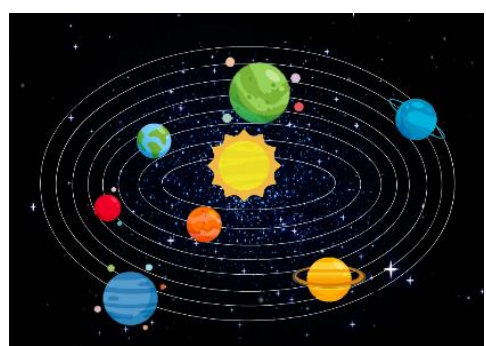

Gambar 6 Tampilan Animasi

Pada pertengahan Materi, terdapat tampilan yang akan menunjukan animasi dari Tata Surya. Pada bagian kiri atas terdapat tombol next dan back, pada bagian kanan atas terdapat tombol menu, dan pada bagian tengah terdapat tombol "LIHAT ANIMASI" yang berfungsi untuk memutar animasi dari Tata Surya.

a. Menu Quiz : berfungsi untuk mengukur kemampuan siswa setelah menggunakan multimedia interaktif. Dalam menu kuis, disajikan soal pilihan ganda berjumlah 10 soal. Pada tampilan awal menu quiz ini terdapat papan untuk menuliskan nama peserta. Terdapat tombol "Play" untuk memulai quiz, 
Sutrisno. Pengembangan Media Tata Surya...

dan juga terdapat tombol "menu" pada bagian kanan atas. Berikut tampilan menu quiz seperti pada gambar 7 dan 8 sebagi berikut.

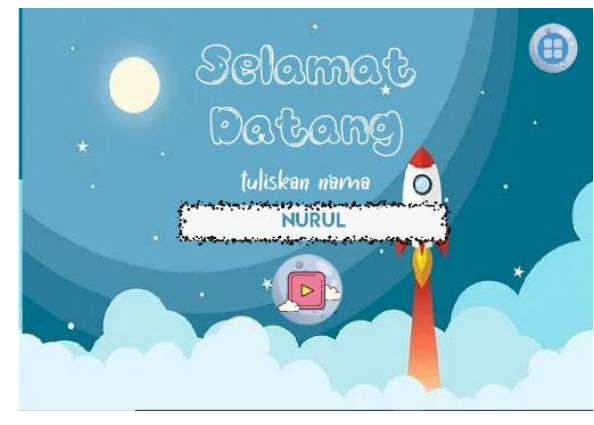

Gambar 7 Tampilan Awal Menu Quiz

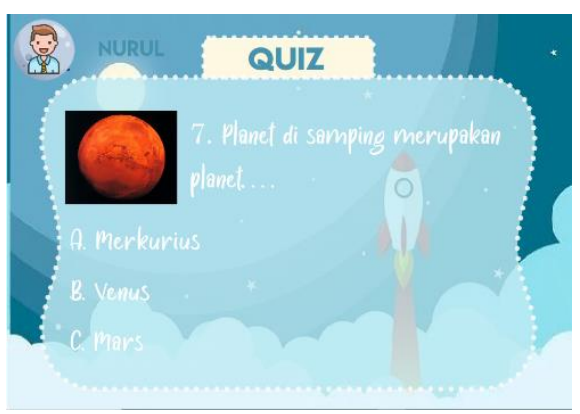

Gambar 8 Tampilan Soal Pilihan Ganda

\section{B. Hasil Validitas}

Sedangkan untuk instrumen pengumpul data pada penelitian pengembangan ini secara rinci dapat di lihat pada tabel di bawah ini.

Tabel 2. Hasil Validitas Produk

\begin{tabular}{|c|c|c|c|c|}
\hline Responden & $\begin{array}{c}\text { Bidang } \\
\text { Keahlian }\end{array}$ & Instrumen & Hasil & Keterangan \\
\hline $\begin{array}{c}\text { Nurita } \\
\text { Primasatya }\end{array}$ & Ahli Media & $\begin{array}{c}\text { Lembar } \\
\text { validasi }\end{array}$ & $90 \%$ & $\begin{array}{c}\text { Sudah sangat baik hanya } \\
\text { memerlukan sedikit perbaikan } \\
\text { terkait dengan penggunaan bagroun } \\
\text { pada beberapa scene yang terlalu } \\
\text { banyak warna sehingga }\end{array}$ \\
\hline $\begin{array}{c}\text { Bagus } \\
\text { Amirul } \\
\text { Mukmin }\end{array}$ & Ahli Materi & $\begin{array}{c}\text { Lembar } \\
\text { validasi }\end{array}$ & $83 \%$ & $\begin{array}{c}\text { Materi sudah sesuai dengan tingkat } \\
\text { perkembangan siswa dan layak } \\
\text { digunakan }\end{array}$ \\
\hline $\begin{array}{c}\text { Abdul Aziz } \\
\text { Hunaifi }\end{array}$ & $\begin{array}{c}\text { Ahli } \\
\text { Bahasa }\end{array}$ & $\begin{array}{c}\text { Lembar } \\
\text { validasi }\end{array}$ & $87 \%$ & $\begin{array}{c}\text { Bahasa sudah sesuai dengan } \\
\text { perkembangan bahasa siswa }\end{array}$ \\
\hline
\end{tabular}

\section{PEMBAHASAN}

Berdasarkan hasil penelitian yang telah dilakukan didapatkan hasil bahwa paroduk media pembelajaran tata surya berbasis mackromedia flash layak digukan dalam pembelajaran sebagi inovasi pembelajaran dan dapat digunakan dalam pembelajaran dalam jaringan (DARING). Menurut Mukmin (2018) multimedia interaktif dipilih untuk memaksimalkan fasilitas teknologi yang sudah tersedia dan memberikan inovasi pembelajaran yang efektif untuk siswa. Media tata surya ini dapat digunakan siswa untuk 
Sutrisno. Pengembangan Media Tata Surya...

belajar di rumah baik mengunakan jaringan internet maupun tanpa jaringan internet tetap bias digunakan. Hasil validitas produk menunjukan bahwa produk media tata surya berbasis macromedia flash valid dan layak digunakan dalam pembelajaran berdasarkan ahli media, materi, dan bahasa. Dibuktikan dengan hasil kevalidan produk berdasarkan ahli media pembelajaran yaitu 90\% dengan kategori sangat layak. Kevalidan produk berdasarkan ahli media meliputi kesesuian gambar, warna, font, tata letak tulisan dan gambar, animasi, dan suara. Sejalan dengan Maskur (2017) yang menyatakan bahwa macromedia flash dari aspek tombol dan grafis layak digunakan. Didukung oleh pendapat (Munadi, 2013) yang menyatakan bahwa kelebihan multimedia interaktif yaitu siswa diajak untuk terlibat secara auditif, visual, dan kinetik sehingga dimungkinkan informasinya mudah dimengerti. Sedangkan dari segi materi berdasarkan ahli materi menunjukan bahwa produk media tata surya sudah sesuai dengan materi yang ada di SD dan sesuai deng tingkat perkembangan siswa dengan prosentase kevalidan mencapai $83 \%$ dengan kategori layak. Validitas materi berdasarkan kesesuaian KI, indikator, materi sesui dengan tingkat perkembangan kognitif anak. Hasil validitas menurut ahli bahasa menunjukan bahwa produk media tata surya sudah sesuai dengan tingkat perkembangan anak dan mudah di pahami dengan prosentase kevalidan mencapai 87\% dengan kategori layak. Menurut Muhson (2010) Media pembelajaran yang dirancang secara baik akan sangat membantu peserta didik dalam mencerna dan memahami materi pelajaran. Sejalan dengan Mukmin (2018) bahan ajar DELIKAN berbasis macromedia flash valid dan layak digunakan dalam pembelajaran di sekolah dasar. Sedangkan menurut aka (2017) TIK dapat digunakan untuk membantu mengemas bahan ajar (Multimedia).

\section{SIMPULAN}

Berdasarkan hasil penelitian dapat disimpulkan bahwa produk media tata surya layak digunakan untuk siswa sekolah dasar. Kelayakan produk media tata surya didasarkan atas hasil validitas produk menurut ahli media, ahli materi, dan ahli bahasa. Hasil kevalidan dibuktikan dengan nilai kevalidan media sebesar 90\%, sedangkan ahli materi $83 \%$, dan berdasarkan ahli bahasa $87 \%$. Dengan demikian produk media tata surya layak dan valid digunakan untuk siswa sekolah dasar dan merupakan media pembelajaran yang inovatif bagi siswa. 
Sutrisno. Pengembangan Media Tata Surya...

\section{DAFTAR RUJUKAN}

Aka, K. A. (2017). Pemanfaatan Teknologi Informasi Dan Komunikasi (TIK) Sebagai Wujud Inovasi Sumber Belajar Di Sekolah Dasar. ELSE (Elementary School Education Journal): Jurnal Pendidikan Dan Pembelajaran Sekolah Dasar, 1(2a).

Milman, N. B. (2015). Distance Education. In International Encyclopedia of the Social \& Behavioral Sciences: Second Edition. https://doi.org/10.1016/B978-0-08097086$\underline{8.92001-4}$

Mukmin, B. A., \& Primasatya, N. (2020). Pengembangan Multimedia Interaktif Macromedia Flash Berbasis K-13 Sebagai Inovasi Pembelajaran Tematik Untuk Siswa Sekolah Dasar. JURNAL PENDIDIKAN DASAR NUSANTARA, 5(2), 211226.

Mukmin, B. A., \& Zunaidah, F. N. (2018). Pengembangan Bahan Ajar DELIKAN Tematik Berbasis Multimedia Interaktif Untuk Siswa Sekolah Dasar di Kota Kediri. Al Ibtida: Jurnal Pendidikan Guru MI, 5(2), 145-158.

Muhson, A. (2010). Pengembangan media pembelajaran berbasis teknologi informasi. Jurnal Pendidikan Akuntansi Indonesia, 8(2).

Maskur, R., Nofrizal, N., \& Syazali, M. (2017). Pengembangan Media Pembelajaran Matematika dengan Macromedia Flash.Al-Jabar: Jurnal Pendidikan Matematika, 8(2), 177-186.

Munadi, Y. (2013). Media Pembelajaran (Sebuah Pendekatan Baru), Referensi. Jakarta: (GP Press Group)

Nopriyanti, N., \& Sudira, P. (2015). Pengembangan multimedia pembelajaran interaktif kompetensi dasar pemasangan sistem penerangan dan wiring kelistrikan di SMK. Jurnal Pendidikan Vokasi, 5(2), 222-235.

Sumarsih, d. M. (2016). Pengembangan Multimedia Akuntasi Biaya Metode Harga Popok Pesanan Bagi Mahasiswa Jurusan Pendidikan Akuntasi UNY. Jurnal Inovasi Teknologi Pendidikan, 3 (1), 92-105.

Wicaksono, S. (2016). The Development of Interactive Multimedia Based Learning Using Macromedia Flash 8 In Accounring Course. Journal of Accounting and Business Education 1 (1), 122-139. 